\title{
Hambatan EGCG terhadap Ekspresi Vascular Endothelial Growth Factor (VEGF) dan Ekspresi Vascular-endothelial Cadherin (VE-Cadherin) dalam Vaskulo-angiogenesis Embrio Ayam
}

\author{
Indriati Dwi Rahayu ${ }^{1 *}$, Mochammad Sasmito Djati ${ }^{2}$, Mohammad Rasjad Indra ${ }^{3}$ \\ ${ }^{1}$ Laboratorium Anatomi Histologi Fakultas Kedokteran Universitas Brawijaya \\ 2Jurusan Biologi, Fakultas Matematika dan ilmu pengetahuan Alam, Universitas Brawijaya \\ ${ }^{3}$ Laboratorium Fisiologi Fakultas Kedokteran Universitas Brawijaya
}

\begin{abstract}
Abstrak
Keamanan konsumsi EGCG terhadap kehamilan, terutama dampaknya terhadap perkembangan embrio sejauh ini belum diketahui. Penelitian ini bertujuan untuk mengetahui pengaruh EGCG terhadap mekanisme vasculo-angiogenesis pada embrio ayam secara in ovo. Telur tetas diinjeksi dengan EGCG sebelum diinkubasi. Kemudian survival rate embrio, ekspresi VEGF dan ekspresi VE-Cadherin pada embrio dibandingkan dan dievaluasi. Dalam penelitian ini, nampak adanya penurunan survival rate embrio, ekspresi VEGF dan VE-Cadherin, sesuai dengan peningkatan dosis paparan EGCG. Hasil tersebut menunjukkan bahwa EGCG dapat mempengaruhi pertumbuhan embrio ayam, melalui hambatan terhadap ekspresi VEGF dan VE-Cadherin.
\end{abstract}

Kata Kunci: EGCG, embrio, angiogenesis, VEGF, VE-Cadherin

\section{PENDAHULUAN}

Perkembangan embrio membutuhkan peningkatan nutrisi, oksigen, serta pembuangan zat-zat sisa metabolime sel. Peningkatan kebutuhan tersebut tidak bisa dipenuhi secara difusi [1], sehingga dibutuhkan sistem baru untuk menjamin kelangsungan hidup dan proses perkembangan embrio. Hal pertama yang terjadi adalah diferensiasi sel-sel mesenkhimal (hemangioblast) menjadi sel endothel sehingga terbentuk pembuluh darah baru secara de novo. Peristiwa ini disebut vaskulogenesis [2,3].

Vaskulogenesis diregulasi oleh berbagai faktor dengan rangkaian peristiwa kompleks. Sel prekursor dari hemangioblast bersifat tergantung terhadap berbagai growth factor antara lain basic fibroblast growth factor 2 (FGF2) dan vascular endothelial growth factor (VEGF) [4]. VEGF sangat penting dalam peristiwa angiogenesis embrional [3]. VE-cadherin (Vascular-endothelial cadherin), suatu protein yang berperan dalam adhesi bagi endothel juga memiliki kaitan interaksi molekuler dengan reseptor VEGF [5]. VE-Cadherin secara eksklusif diekspresikan di sel endothel dan hanya diekspresikan di angioblast.

\footnotetext{
* Alamat korespondensi:

Indriati Dwi Rahayu

Email : indri_fkub@yahoo.com

Alamat : Laboratorium Anatomi Histologi Fakultas Kedokteran Universitas Brawijaya, Jl. Veteran, Malang, 65145
}

VE-Cadherin diketahui berperan dalam mengorganisir adherent junction di sel endothel yang mengatur adhesi antar sel, permeabilitas, dan migrasi sel endothel $[3,6]$. Peristiwa ini diikuti dengan angiogenesis, yaitu terbentuknya cabang pembuluh darah baru melalui pemanjangan pembuluh darah kecil yang ada sebelumnya [7]. Angiogenesis diperlukan dalam proses pertumbuhan embrio, maupun proses-proses perbaikan fisiologis saat postnatal. Proses vaskulo-angiogenesis pada embrio sering dipelajari dengan menggunakan embrio ayam (maupun famili aves lainnya) karena lebih mudah dipelajari [3,8], serta untuk mengurangi penggunaan mamalia sebagai hewan coba [9].

Angiogenesis yang berjalan abnormal mengakibatkan berbagai proses patologis. Istilah abnormalitas ini meliputi proses angiogenesis yang berlebihan maupun yang mengalami hambatan [10]. Proses angiogenesis yang berlebihan dapat dihambat oleh zat yang disebut sebagai anti angiogenik [7]. Salah satu zat antiangiogenik yang akhir-akhir ini menjadi pusat perhatian adalah EGCG (Epigallocatechin-3gallate), zat aktif utama dalam teh hijau [11].

Mekanisme EGCG dalam menghambat angiogenesis ditunjukkan dalam beberapa laporan penelitian, meskipun masih belum sepenuhnya diketahui [12]. Secara in vitro, EGCG dilaporkan dapat menghambat pembentukan tabung vaskular dari sel pembentuknya, melalui inhibisi terhadap VEGF serta hambatan terhadap 
fosforilasi VE-cadherin [13]. Berdasarkan hasil penelitian Park pada tahun 2006 diketahui efek anti-angiogenik EGCG terjadi melalui hambatan terhadap ekspresi VEGF yang diinduksi PDGF (Platelet-derived Growth Factor) di berbagai level signaling [14]. Sejalan dengan itu, Zhu et al., membuktikan bahwa EGCG menghambat proliferasi sel endothel (yang diinduksi VEGF), migrasi sel endothelial, dan pembentukan tabung vaskular, bahkan EGCG diketahui dapat mengurangi densitas vaskular pada beberapa jenis tumor $[15,16]$.

Penelitian mengenai pengaruh EGCG terhadap embrio masih sangat terbatas. Sejauh ini belum diketahui dampak EGCG terhadap kehamilan pada manusia tetapi EGCG pernah dilaporkan dapat menyebabkan hambatan pertumbuhan caudal pada embrio tikus mulai dosis $25 \mathrm{mgl}^{-1}$ [17]. Gangguan pertumbuhan kaudal disebabkan oleh gangguan mekanisme vaskulo-angiogenesis, yang dapat dihambat oleh EGCG. Sejauh ini belum ada penelitian yang menjelaskan keterkaitan hal tersebut. Oleh karena itu, penelitian ini bertujuan untuk mengetahui pengaruh EGCG pada embrio secara in ovo terutama terkait dengan proses vaskuloangiogenesis. Beberapa parameter representatif yang digunakan dalam penelitian ini adalah ekspresi VEGF, VE-cadherin, serta sirkulasi yolk sac.

\section{METODE PENELITIAN}

Penelitian ini menggunakan rancangan randomized control group post test design. Percobaan dilaksanakan di Laboratorium Biomedik Fakultas Kedokteran Universitas Brawijaya.

Hewan coba yang digunakan adalah ayam (Gallus gallus strain Cobb) fase embrio dalam telur ayam. Telur yang telah dibuahi, diperoleh dari perusahaan pembibitan ayam PT Randu Agung Jaya, Kabupaten Malang. Tahap perkembangan embrio ayam mengikuti tabel Hamburger and Hamilton [18]. Hewan coba dibagi secara acak menjadi 4 kelompok $(n=7)$ yaitu kelompok kontrol negatif (hanya injeksi PBS), kelompok perlakuan EGCG dengan dosis $12,5 \mathrm{mgl}^{-1}$, kelompok perlakuan EGCG dengan dosis $25 \mathrm{mgl}^{-1}$, dan kelompok perlakuan EGCG dengan dosis $25 \mathrm{mgl}^{-1}$.

Semua perlakuan dilakukan in ovo secara injeksi dengan menggunakan dispossible syringe $1 \mathrm{cc}$ sedalam $0,5 \mathrm{~cm}$. Injeksi dilakukan pada ujung tumpul telur. Sebelum injeksi, area injeksi diusap dengan alkohol dispossable. Setelah selesai injeksi, ditutup dengan vinyltape. Kemudian posisi telur dibalik $180^{\circ}$ sesuai aksisnya. Kemudian diinkubasi pada suhu $37,5-38,5{ }^{\circ} \mathrm{C}$ selama 48 jam[19].

Perhitungan Sirkulasi Yolk sac.

Telur dipecahkan, dan isinya dituang ke dalam cawan yang setengahnya berisi Larutan $\mathrm{NaCl}$ $0,9 \%$ (NS). Embrio dengan sirkulasi yolk sac atau setidaknya blood island dianggap embrio yang berhasil bertahan hidup (survive). Jumlah embrio yang dapat bertahan hidup dibagi dengan jumlah telur dalam tiap kelompok dinyatakan sebagai survival rate.

Pengambilan dan penyimpanan bahan coba

Bingkai kertas saring diletakkan di atas blastodisk (embrio), kemudian vitelinne membrane digunting di sisi luar bingkai kertas. Bingkai kertas saring diangkat, sehingga embrio berada dalam lubang pada bingkai kertas saring. Spesimen dimasukkan dalam larutan $\mathrm{NaCl}$ 0,9\% yang lain, kemudian dipindahkan lagi dalam larutan NS yang lain dan digoyang-goyangkan beberapa kali. Spesimen dimasukkan dalam Carnoy's fluid (CF), dan dibiarkan beberapa jam (antara 4-12 jam) [20].

Larutan CF diganti dengan cara diaspirasi dengan pipet, kemudian diganti dengan alkohol $70 \%$ dengan menggunakan pipet. Alkohol diganti dengan alkohol $70 \%$ yang baru. Spesimen siap untuk dicat, dalam hal ini dengan pengecatan imunohistokimia. Spesimen dapat disimpan paling lama satu bulan [21].

Immunohistokimia

Pengecatan imunohistokimia dilakukan untuk melihat ekspresi VEGF dan VE-Cadherin dengan menggunakan anti VEGF dan anti VE-Cadherin (Sigma). Sediaan (preparat) diamati dengan mikroskop perbesaran mikroskop 50 kali. Gambar 2D diambil dengan menggunakan kamera digital Olympus Camedia C-4000, dengan perbesaran maksimal. Hasil foto dicetak dalam ukuran 5R.

Perhitungan dengan pendekatan Stereologis.

Ekspresi VEGF dan ekspresi VE-Cadherin dinyatakan dalam persentase area dan estimasi luas area. Perhitungan dilakukan secara manual dengan pendekatan stereologis menggunakan kisi-kisi atau test grid (Gambar 1).

Batasan embrio ditentukan terlebih dahulu secara manual. Gambar 2D ditempatkan tumpang tindih dengan kisi-kisi yang tercetak di atas mika. Jumlah titik potong (intersection) dihitung pada area yang diperlukan. Perhitungan dilakukan oleh 2 (dua) orang observer. Jumlah titik potong adalah perhitungan manual jumlah titik potong (intersection) yang berada di area 
yang dimaksud (area of interest), pada gambar yang telah dipasang test grid. Hasil perhitungan titik kemudian dirata-rata untuk perhitungan lebih lanjut. Dilakukan persentase area dengan rumus perhitungan sebagai berikut :

Persentase area $(\%)=\underline{\Sigma}$ titik dengan reaksi positif $\times 100$ $\Sigma$ titik dalam embrio

Dilakukan penghitungan estimasi luas area ekspresi VEGF dan VE-Cadherin dengan rumus:

Luas area $\left(\mathrm{mm}^{2}\right)=\Sigma$ titik dengan reaksi positif $\mathrm{x}(\mathrm{a} / \mathrm{p})$

$(\mathrm{a} / \mathrm{p})=(\text { jarak } 2 \text { titik dalam grid })^{2} /$ perbesaran $^{2}$

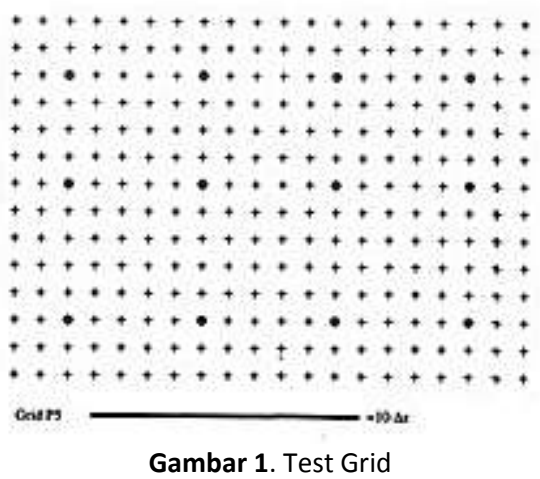

\section{Analisis Data}

Uji hipotesis Chi Square digunakan terhadap data sirkulasi yolk sac dan survival rate, karena merupakan variabel nominal. Data dengan variabel numerik (ekspresi VEGF dan VECadherin) dianalisa dengan analisis varian (ANOVA) [23].

\section{HASIL DAN PEMBAHASAN}

Vaskulo-angiogenesis merupakan rangkaian kejadian yang melibatkan banyak mekanisme dan faktor. Proses vaskulo-angiogenesis memerlukan berbagai jalur signaling kompleks yang terintegrasi. Koordinasi sinyal mitogenik dan antiproliferatif berperan dalam mengatur perkembangan sistem vaskular embrio [24]. Faktor vaskulo-angiogenesis yang menjadi fokus dalam penelitian ini adalah VEGF dan VECadherin, sebagai molekul yang sangat penting dalam vaskulo-angiogenesis. Selain itu, dalam penelitian ini juga diamati sirkulasi yolk sac, sebagai indikator keberhasilan proses vaskuloangiogenesis ekstraembrional pada embrio ayam Ekspresi VEGF

Ekspresi VEGF dinyatakan dalam persentase area, estimasi luas area (area yang memberikan reaksi positif terhadap antibodi primer dengan pengecatan imunohistokimia), serta integrated density yang diperoleh dari perhitungan software ImageJ. Pada penelitian ini didapatkan bahwa paparan EGCG dapat menurunkan ekspresi VEGF (Gambar 2).

a.
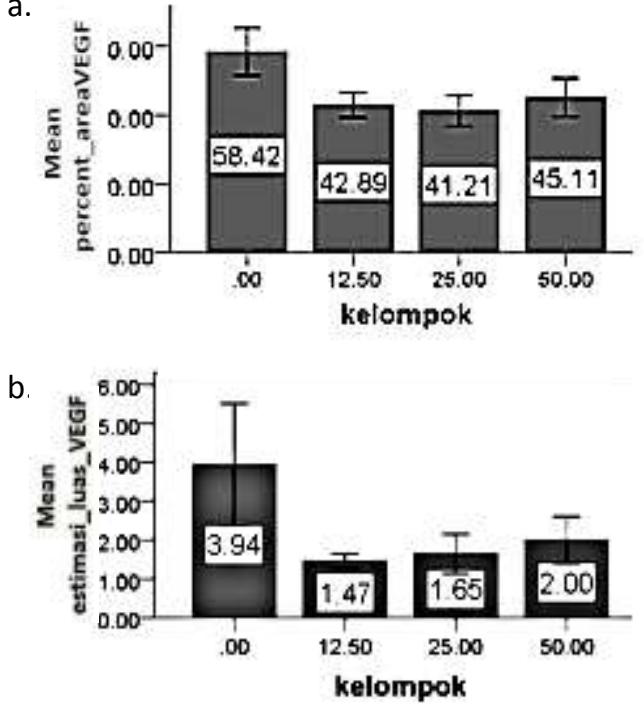

C.

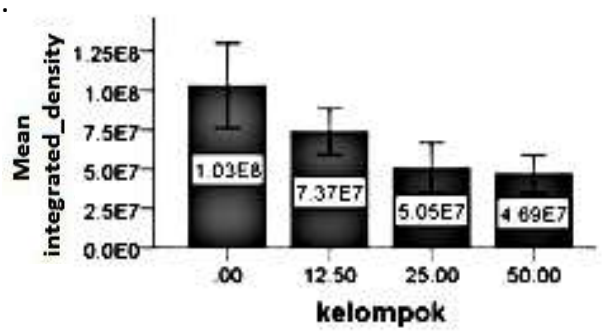

Gambar 2. Grafik Hasil Perhitungan Ekspresi VEGF Keterangan:

a. Persentase area VEGF

b. Estimasi Luas VEGF

c. Integrated density VEGF

Persentase area merepresentasikan perbandingan area yang mengandung VEGF dengan keseluruhan embrio. Hasil perhitungan kuantifikasi dengan stereologi, didapatkan persentase area VEGF kelompok perlakuan berkurang dibanding kelompok kontrol, meski secara statistik tidak bermakna $(p=0,62)$. Hal tersebut mengindikasikan bahwa paparan EGCG dapat menurunkan persentase area VEGF. Fakta ini menunjukkan kemungkinan bahwa VEGF diekspresikan lebih sedikit, atau dengan distribusi yang lebih sempit.

Berdasarkan area yang memberikan reaksi positif terhadap antibodi primer VEGF, didapatkan perkiraan luas VEGF kelompok perlakuan berkurang dibanding kelompok kontrol, meski secara statistik tidak bermakna $(p=0,28)$. Hal ini disebabkan VEGF diekspresikan dengan area distribusi yang lebih sempit. 
Densitas seringkali diasumsikan sebagai representasi konsentrasi. Hasil metode kuantifikasi densitas VEGF dengan software "imageJ", diperoleh data penurunan densitas VEGF pada kelompok kontrol dibandingkan dengan kelompok perlakuan, meski secara statistik tidak bermakna $(p=0,17)$. Hasil tersebut menggambarkan kemampuan EGCG dalam mempengaruhi densitas VEGF. Semakin besar dosis EGCG, penurunan densitas VEGF juga semakin besar, sehingga diduga konsentrasi VEGF yang diekspresikan juga semakin kecil.

Salah satu fungsi utama VEGF adalah untuk mendukung diferensiasi angioblast menjadi endothel [25]. VEGF juga berperan penting dalam melindungi sel endothel dari kematian akibat apoptosis selama perkembangan embrional [3]. Fungsi supresi apoptosis oleh VEGF dimediasi oleh aktivasi MAPK dan PI3K/Akt [26].

VEGF pada mulanya diekspresikan pada bagian anterior embrio. Sedangkan sel yang mengekspresiakan VEGFR-1 dan VEGFR-2 berada pada bagian posterior. Maka Interaksi VEGF-A dan Reseptor-reseptor VEGF (VEGFRs) diduga terlibat dalam migrasi sel prekursor hemangioblast pada awal embrio. Migrasi sel prekursor hemangioblast pada embrio merupakan tahap penting dalam pembentukan anyaman kapiler [4]. VEGFR-2/FIk1 juga diekspresikan oleh hemangioblast yang berasal dari wilayah di mana mesoderm berhubungan dengan endoderm visceral dan berpartisipasi dalam pembentukan pembuluh darah ekstraembrionik pada yolk sac [27].

Interaksi VEGF dan VEGFR menjadi salah satu dasar mekanisme dalam angiogenesis. Substansi yang menghambat salah satu atau keduanya dapat menghambat angiogenesis, sehingga disebut sebagai zat/substansi antiangiogenik. Salah satu substansi antiangiogenik yang cukup banyak mendapat perhatian akhir-akhir ini adalah EGCG.

EGCG sebagai zat anti angiogenik bekerja melalui beberapa cara. Di tingkat hulu, EGCG dapat menekan HIF-1A, yang berakibat pada penurunan ekspresi VEGF [27]. EGCG juga menghambat pembentukan tabung vaskular dari sel pembentuknya, melalui inhibisi terhadap VEGF serta hambatan terhadap fosforilasi VEcadherin [13]. Park et al., melaporkan bahwa EGCG dapat menunjukkan efek anti-angiogenik melalui hambatan terhadap ekspresi VEGF yang diinduksi PDGF (Platelet-derived Growth Factor) melalui berbagai level signaling [14]. Zhu et al., membuktikan EGCG menghambat proliferasi sel endothel (yang diinduksi VEGF), serta menghambat migrasi sel endothelial dan pembentukan tabung vaskular $[15,28]$. Kemampuan anti-angiogenik lain EGCG juga ditunjukkan dalam hambatan terhadap diferensiasi sel endothel serta hambatan potensi remodeling matriks ekstraseluler [29]. EGCG juga dilaporkan mampu menghambat pembentukan kompleks VEGF dengan VEGFR-2, serta mengganggu signaling VEGF intraseluler [13].

Hambatan kinerja VEGF dalam berbagai level dan mekanisme oleh EGCG sebagaimana banyak penelitian yang telah dilakukan, sesuai dengan hasil penelitian ini. Hal tersebut dapat menjelaskan tren penurunan ekspresi VEGF dalam penelitian ini. Hambatan EGCG terhadap proliferasi, migrasi, dan pembentukan tabung vaskular sejalan dengan penurunan luas ekspresi dan persentase area VEGF dalam penelitian ini. Penurunan densitas VEGF dipengaruhi oleh hambatan EGCG terhadap ekspresi VEGF oleh selsel embrional.

a.

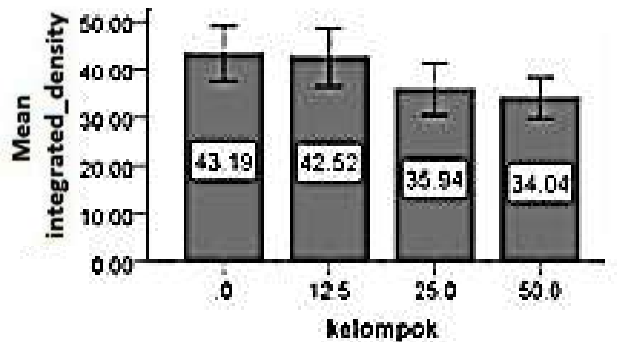

b.

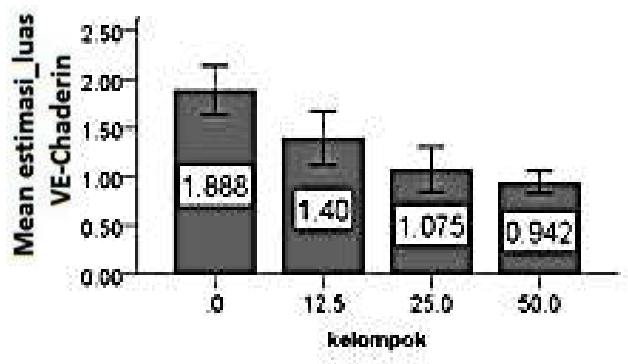

c.

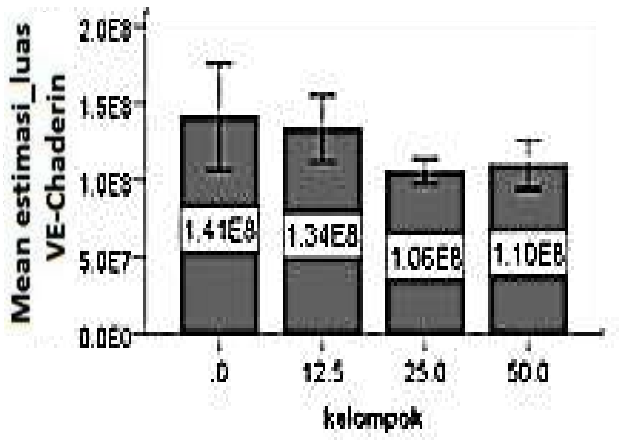

Gambar 3. Grafik Hasil Perhitungan Ekspresi VEGF Keterangan:

a. Persentase area VE-Cadherin

b. Estimasi Luas VE-Cadherin

c. Integrated density VE-Cadherin 


\section{Ekspresi VE-Cadherin}

Dalam penelitian ini diketahui bahwa paparan EGCG juga dapat menurunkan ekspresi VECadherin (Gambar 3). Hasil metode kuantifikasi dengan stereologi, didapatkan persentase area VE-Cadherin kelompok perlakuan menunjukkan kecenderungan menurun dibanding kelompok kontrol, meski secara statistik tidak bermakna $(p=0,57)$. Hal tersebut mengindikasikan bahwa paparan EGCG dapat menurunkan persentase bahwa VE-Cadherin diekspresikan lebih sedikit, atau dengan distribusi yang lebih sempit.

Perkiraan luas area yang memberikan reaksi positif terhadap antibodi primer VE-Cadherin, didapatkan luas VE-Cadherin kelompok perlakuan berkurang secara nyata dibanding kelompok kontrol $(p=0,048)$. Hal ini menunjukkan kemungkinan distribusi ekspresi VE-Cadherin menjadi lebih sempit dengan paparan EGCG.

Hasil metode kuantifikasi densitas VECadherin dengan software imageJ, menunjukkan terdapat tren penurunan densitas VE-Cadherin pada kelompok kontrol dengan kelompok perlakuan, meski secara statistik tidak bermakna. $(p=0,78)$. Hasil tersebut secara tidak langsung menggambarkan kemampuan EGCG dalam mempengaruhi konsentrasi VE-Cadherin, karena konsentrasi dalam hal ini direpresentasikan oleh densitas VE-Cadherin.

VE-Cadherin atau Cadherin-5 atau CD144 secara eksklusif diekspresikan di sel endothel. VEcadherin hanya diekspresikan di angioblast, bukan di sel progenitor hematopoietik, meski pernah dilaporkan ekspresi sesaat VE-Cadherin di hepar fetus. VE-Cadherin diketahui memiliki peran dalam mengorganisasi adherent junction di sel endothel. VE-Chaderin mengatur adhesi antar sel, permeabilitas, dan migrasi sel endothel $[3,6]$. VE-cadherin memediasi interaksi antara sel-sel endothel yang bersifat calcium-dependent homophilic [30]. Defisiensi atau putusnya gen ini bersifat lethal, akibat apoptosis sel endothel $[5,30]$. VE-cadherin, juga memiliki kaitan interaksi molekuler dengan VEGFR [5].

Hambatan pada VE-Cadherin juga akan menghambat angiogenesis. Dengan demikian, zat yang dapat menghambat VE-Cadherin juga bersifat anti angiogenik. Salah satu contoh substansi angiogenik adalah EGCG.

EGCG menghambat pembentukan tabung vaskular dari sel pembentuknya, melalui inhibisi terhadap VEGF serta hambatan terhadap fosforilasi VE-cadherin, sehingga terjadi gangguan ekspresi VE-Cadherin [13]. Gangguan ekspresi VE-Cadherin akan mengakibatkan gangguan dalam tube formatian pembuluh darah, sehingga pembuluh darah yang terbentuk tidak berfungsi optimal. Hal tersebut menjelaskan tren penurunan ekspresi VECadherin dalam penelitian ini.

Dalam penelitian ini, efek EGCG dalam menghambat pembentukan tabung vaskular memberikan dugaan keterkaitan dengan penurunan persentase area dan luas area ekspresi VE-cadherin. Penurunan densitas VECadherin diduga disebabkan hambatan ekspresi VE-Cadherin oleh sel-sel endothel. Tetapi, karena embrio masih dalam tahap awal, VE-Cadherin belum terekspresi secara maksimal. Sehingga perubahan tersebut tidak terlalu besar.

Luas area VEGF lebih luas dibandingkan dengan luas VE-Cadherin. Hal ini diduga disebabkan distribusi VEGF yang meliputi intraseluler hingga ekstra seluler, sedangkan ekspresi VE-Cadherin hanya terbatas pada permukaan sel. Selain itu, VEGF juga terlebih dahulu terkspresi bila dibandingkan dengan VECadherin.

\section{Sirkulasi Yolk sac}

Pengamatan proses vaskulo-angiogenesis ekstraembrional, diwakili dengan adanya blood island atau sirkulasi yolk sac pada telur ayam. Blood island atau sirkulasi yolk sac menunjukkan bahwa embrio mampu bertahan hidup, dan telah terjadi proses vaskulo-angiogenesis pada embrio. Dalam penelitian ini terdapat penurunan sirkulasi yolk sac yang bermakna $(p=0,01)$ dengan paparan EGCG selama 48 jam (Gambar 4 dan 5)

a.
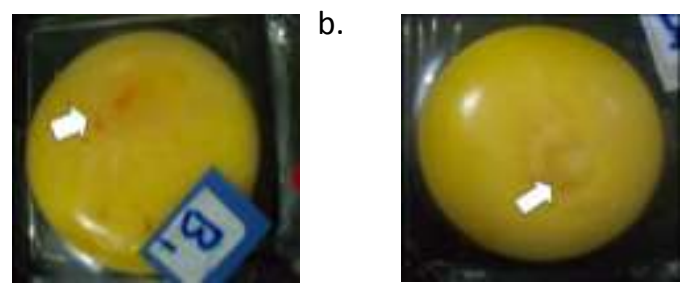

c.

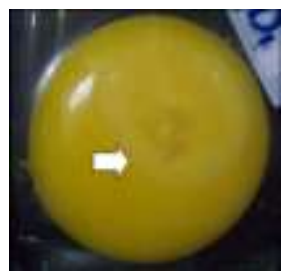

Gambar 4. Penentuan Yolk sac Circulation, Blood island, dan kematian embrio

Keterangan:

a :Embrio dengan Yolk sac Circulation

b :Embrio dengan blood island

c :Embrio yang gagal tumbuh, tanpa blood island maupun Yolk sac Circulation. Embrio diasumsikan mati 


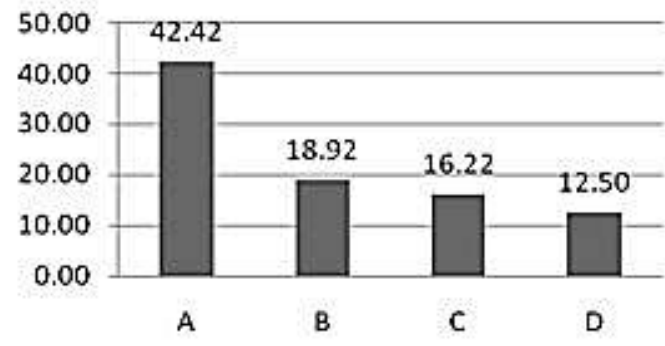

Gambar 5. Grafik hasil pengamatan keberadaan sirkulasi pada yolk sac embrio 48 jam

Keterangan :

a : Kelompok telur yang hanya diinjeksi PBS

b : Kelompok telur yang diinjeksi EGCG $12,5 \mathrm{mgl}^{-1}$

c : Kelompok telur yang diinjeksi EGCG $25 \mathrm{mgl}^{-1}$

$\mathrm{d}$ : Kelompok telur yang diinjeksi EGCG $50 \mathrm{mgl}^{-1}$

\section{Kelangsungan hidup (Survival rate) embrio}

Embrio dianggap hidup jika pada saat telur dibuka, nampak ada blood island atau pembuluh darah pada blastodisk. Jika tidak terdapat blood island maka embrio tersebut sudah mati atau gagal tumbuh.

Pada kelompok A, sebanyak 75,76\% embrio menunjukkan tanda-tanda kehidupan dalam batas normal. Sedangkan pada kelompok perlakuan, nilai survival rate menurun sesuai dengan peningkatan dosis perlakuan (Gambar 6). Berdasaekan hasil perlakuan yang ditampilkan pada Gambar 6, diketahui terdapat penurunan survival rate yang siganifikan $(p=0,024)$.

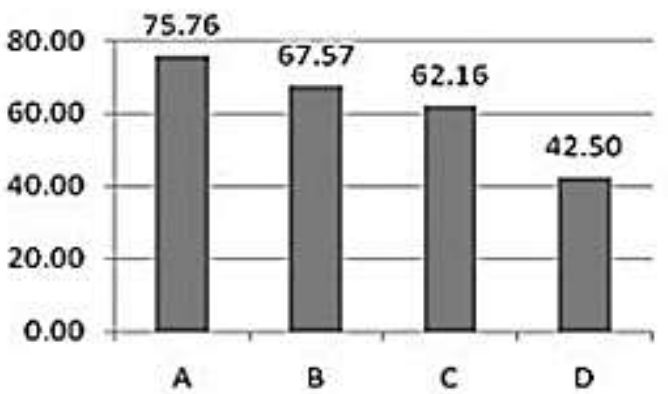

Gambar 6. Grafik Survival rate embrio 48 jam Keterangan

a : Kelompok telur yang hanya diinjeksi PBS

b : Kelompok telur yang diinjeksi EGCG $12,5 \mathrm{mgl}^{-1}$

c : Kelompok telur yang diinjeksi EGCG $25 \mathrm{mgl}^{-1}$

$\mathrm{d}$ : Kelompok telur yang diinjeksi EGCG $50 \mathrm{mgl}^{-1}$

Vaskulo-angiogenesis merupakan hal penting dalam survival embrio, karena tanpa supply darah yang memadai, maka kebutuhan nutrisi dan oksigenasi sel akan terhenti, dan mengakibatkan kematian sel. $\mathrm{Hal}$ ini dapat menjelaskan hasil penelitian oleh Wang pada tahun 2007 bahwa paparan EGCG menyebabkan retardasi caudal pada embrio tikus [17]. Selain itu, penurunan survival dari embrio dalam penelitian ini diduga juga terkait dengan hambatan angiogenesis, di mana telah diketahui bahwa angiogenesis dapat dihambat oleh EGCG secara in vitro dan in vivo $[13,14]$. Paparan EGCG yang mengakibatkan gangguan angiogenesis akan menyebabkan gangguan supply pembuluh darah ke jaringan perifer, sehingga berujung pada kegagalan tumbuh hingga kematian jaringan. Hal inilah yang kemungkinan mengakibatkan terjadinya retardasi kaudal pada penelitian Wang tersebut. Untuk memastikan hal tersebut, tentunya diperlukan penelitian lebih lanjut.

Dalam penelitian ini, survival embrio nampak menurun dengan peningkatan dosis perlakuan EGCG. Hal ini kemungkinan disebabkan oleh banyak faktor. Faktor internal diakibatkan kondisi embrio pada awal-awal kehidupan merupakan masa yang rentan terhadap pengaruh luar. Embrio ayam hingga usia 48 jam, serupa dengan embrio masa preimplantasi pada mamalia (tikus dan manusia). Embrio masa preimplantasi sangat rentan terhadap pengaruh dari luar. Faktor eksternal yang berperan dalam penelitian adalah EGCG, yang diduga mempengaruhi banyak faktor internal, yang mengakibatkan penurunan survival embrio. Beberapa faktor survival dalam preimplantasi dipengaruhi oleh paparan EGCG. Faktor tersebut antara lain glukosa, faktor antiapoptosis, dan angiogenesis.

Penggunaan glukosa sangat penting dalam fase preimplantasi. Penurunan transpor glukosa meski tidak serta merta menyebabkan kematian, diduga dapat memicu proses apoptosis. Transpor glukosa banyak dimediasi oleh jalur PI-3K. PI-3K adalah jalur yang merupakan target kerja dari EGCG. Hal ini dapat mengakibatkan gangguan jalur signaling $\mathrm{PI}-3 \mathrm{~K}$, yang mengakibatkan gangguan transpor dan utilisasi glukosa, sehingga dapat memicu proses apoptosis. Selain itu, dilaporkan bahwa 30-phosphorylated Ptdlns yang dihasilkan PI3 kinase berperan dalam cell survival serta memediasi ligan tropic dalam embrio fase preimplantasi pada mamalia [31]. Dalam penelitian yang lain dilaporkan bahwa hambatan PI3K dan selanjutnya dapat menghambat sel HUVEC dalam bermigrasi dan tube formation [32].

Faktor survival lain yang dapat dipengaruhi EGCG adalah Bcl-2 [33]. BCl-2 diketahui berfungsi sebagai faktor anti apoptosis [34]. Dalam hal ini adalah antiapoptosis terhadap sel-sel angioblast. Apoptosis akibat hambatan $\mathrm{BCl}-2$ mengakibatkan kegagalan pembentukan pembuluh darah dari sel-sel angioblast. 
Efek EGCG terhadap kemungkinan terjadinya apoptosis sel-sel pada embrio dalam penelitian ini, sejalan dengan penelitian Wang pada tahun 2007. Wang menunjukkan paparan EGCG mengakibatkan kematian sel-sel embrio tikus akibat apoptosis [17].

\section{Kajian Metode}

Hasil analisa statistik dalam penelitian ini seringkali memberikan ' $P$ ' yang tidak signifikan atau tidak bermakana $(P>0,05)$. Nilai $P$ yang tidak bermakna tersebut diduga karena sampel yang digunakan terlalu sedikit. Semakin banyak sampel, maka nilai $P$ semakin kecil. Oleh karena itu, hasil dapat dibandingan dengan Cohen's $d$ type effect size [35].

Rumus Cohen's d type effect size [36] :

Rerata Kelompok Kontrol - Rerata Kelompok Perlakuan Standar Deviasi Kelompok Kontrol

Interpretasi Cohen's d type effect size :

$0,2-0,5$ : kecil

$0,5-0,8$ : sedang

$>0,8 \quad$ : luas

Berdasarkan perhitungan Cohen's d-type effect size, beberapa hasil menjadi cukup signifikan, karena memiliki hasil effect size $>0,5$ (data tidak ditampilkan). Tetapi, perhitungan effect size ini tidak dapat diterapkan pada data nominal seperti pada data survival rate dan sirkulasi yolk sac.

\section{KESIMPULAN DAN SARAN \\ Kesimpulan}

Paparan EGCG pada embrio ayam menyebabkan hambatan vaskulo-angiogenesis melalui penekanan ekspresi VEGF dan VECadherin yang berakibat sirkulasi darah pada yolk sac berkurang. Hal tersebut mengakibatkan penurunan daya hidup (survival) serta menghambat pertumbuhan embrio ayam.

Saran

Immunohistokimia dengan analisis bersifat semikuantitatif dipergunakan dalam penelitian ini. Meskipun metode ini secara ilmiah dapat dipertanggungjawabkan, tetapi sebaiknya dilakukan penelitian lanjutan dengan metode kualitatif, misalnya ELISA.

\section{DAFTAR PUSTAKA}

1. Sadler, TW. 1995. Langman's Medical Embriology. 7th edition. William \& Wilkins. Baltimore.

2. Bertolino $P$, Deckers $M$, Lebrin F, ten Dijke P. 2005. Transforming Growth Factor-P Signal
Transduction in Angiogenesis and Vascular Disorders. Chest. 128. 585S-590S

3. Ferguson J., Kelley RW, Patterson C. 2005. Mechanisms of Endothelial Differentiation in Embrionic Vasculogenesis. Arterioscler Thromb Vasc Biol. 25. 2246-2254.

4. Hiratsuka S, Kataoka Y, Nakao K, et al. 2005. Vascular endothelial growth factor A (VEGF-A) Is Involved in Guidance of VEGF ReceptorPositive Cells to the Anterior Portion of Early Embrios. Molecular an Cellular Biology. 25. 1: 355-363.

5. Veikkola $\mathrm{T}$, Karkkainen $\mathrm{M}$, Claesson-Welsh L, Alitalo K. 2000. Regulation of Angiogenesis via Vascular endothelial growth factor Receptor. Cancer Research. 60. 203-212

6. Abbas AK, Lichtman AH. 2003. Cellular and Molecular Immunology. 6th edition. Elsevier Science. Philadelphia.

7. Felmeden DC, Blann AD, Lip GYH. 2003. Angiogenesis : Basic Pathophysiology and Implications for Disease. European Heart Journal. 24. 586-603.

8. Flamme I, Risau W. 1992. Induction of vasculogenesis and. hematopoiesis in vitro. Development. 116: 435-439,

9. Yoshiyama Y, Sugiyama T, Kanke M. 2005. Experimental Diabetes Model in Chick Embrios Treated with Streptozotocin. Biol. Pharm. Bull. 28. 10: 1986-1988.

10. Folkman J, Shing Y. 1992. Angiogenesis. The Journal of Biological Chemistry. 267. 16: 10931-10934,1392.

11. Fassina G, Roberta Vene` $R$, Morini $M$, et al. 2004. Mechanisms of Inhibition of Tumor Angiogenesis and Vascular Tumor Growth by Epigallocatechin-3-Gallate. Clinical Cancer Research. 10:4865-4873

12. Jung YD, Ellis LM. 2001. Inhibition of Tumour Invasion and Angiogenesis by epigallocatechin gallate (EGCG), a Major Component of Green Tea. Int J. Exp. Path. 82:309-316.

13. Rodriguez S.K., et al. 2006. Green tea catechin, epigallocatechin-3-gallate, inhibits vascular endothelial growth factor angiogenic signaling bydisrupting the formation of a receptor complex. Int J Cancer. 118 7:16351644

14. Park HY, Kwon HM, Lim HJ, et al. 2001. Potential role of leptin in angiogenesis: leptin induces endothelial cell proliferation and expression of matrix metal lopratei nases in vivo and in vitro. Exp Mol Med. 30. 2: 95A02.

15. Zhu BH, Zhan WH, Li ZR, et al. 2007. Epigallocatechin-3-gallate inhibits growth of 
gastric cancer by reducing VEGF production and angiogenesis. World Journal of Gastroenterology. 13. 8: 1162-1169.

16. Spinella F, Rosanò L, Di Castro V, et al. Green Tea Polyphenol epigallocatechin-3-gallate inhibits the endothelia axis and downstream signaling pathways in ovarian carcinoma. Mol Cancer Ther. 2006; 5(6):1483-1492

17. Wang CC, Chu KO, Chong WS, et al. 2007. Tea epigallocatechin-3-gallate increases 8isoprostane level and induces caudal regression in developing rat embrios. Free Radical Biology \& Medicine. 43:519-527

18. Hamburger V, Hamilton L. 1951. A series of normal stages in the development of the chick embrio. J. Morphol. 88:49-92.

19. Drake VJ, Koprowski S, Lough JW, Smith SM. 2006. Gastrulating Chick Embrio as a Model for Evaluating Teratogenicity: A Comparison of Three Approache. Birth Defects Research (Part A). 66-71

20. Mason I. 1999. Chick Embrios, Incubation and Isolation. In Sharpe PT, Mason I (eds). Molecular Embrology, Methods and Protocols. Humana Press. New Jersey:

21. Desmond ME, Haas PA. 2000. Experimental Manipulation and Morphometric Analysis of Neural Tube Development. In Tuan RS, Lo CW, (eds). Developmental Biology Protocols Volume II. Humana Press. New Jersey

22. Howard V, Reed MG. 1998. Unbiased Stereology: Three-Dimensional Measurement in Microscopy. Bios Scientific.

23. Dahlan MS. 2004. Statistika untuk Kedokteran dan Kesehatan. Cetakan 1. PT. Arkans. Jakarta

24. Bohnsac BL, Hirchi KK. 2004. Red Light, Green Light:Signals that Control Endothelial Cell Proliferation During Embrionic Vascular Development. Cell Cycle. 3. 12: 1506-1511.

25. Kubo H. and Alitalo K. 2003. The Bloody Fate of Endothelial Stem cells. Genes \& Dev. 17:322-329

26. Dimmeler S, Zeiher A. 2000. Endothelial Cell Apoptosis in Angiogenesis and Vessel Regression. Circ Res. 87 :434-439.

27. Zhang QZ, Tang XD, Lu QY, Zhang ZF, Rao JY, Le AD. 2006. Green tea extract and (_)epigallocatechin-3-gallate inhibit hypoxia- and serum-induced HIF-1A protein accumulation and VEGF expression in human cervical carcinoma and hepatoma cells. Mol Cancer Ther. 5.5:1227-38.

28. Lamy S. Gingras D, B'liveau R. 2002. Green Tea Catechins Inhibit Vascular endothelial growth factor Receptor Phosphorylation. Cancer Research. 62:381-385.

29. Melgarejo E, Medina MA, Sánchez-Jiménez F, et al. 2007. (-)-Epigallocatechin-3-gallate interferes with mast cell adhesiveness, migration and its potential to recruit monocytes. Cell. Mol. Life Sci. 64: 2690 2701

30. Liekens S, De Clercq E, Neyts J. 2001. Angiogenesis: regulators and clinical applications, Biochemical Pharmacology. 61 : 253-270

31. Riley JK, Moley KH. Glucose utilization and the PI3-K pathway: mechanisms for cell survival in preimplantation embrios. Reproduction. 2006; $131823-835$

32. Shankar S, Chen QH, Srivastava RK. 2008. Inhibition of PI3K/AKT and MEK/ERK pathways act synergistically to hrough activation of FOXO transcription enhance antiangiogenic effects of EGCG tfactor. Journal of Molecular Signaling. 3:7: 1-11

33. Khan N, Afaq F, Saleem M, Ahmad N, Mukhtar $\mathrm{H}$. Targeting Multiple Signaling Pathways by Green Tea Polyphenol (-Epigallocatechin-3-Gallate. Cancer Res. 2006; 66(5): 2500-2505

34. Hardy K. 1999. Apoptosis in the human embrio. Reviews of Reproduction. 4. 125-134

35. Kain ZN, MacLaren J. Less Than .05: What Does It Really Mean? Pediatrics. 2007. 119. 608-610

36. Feys H, De Weerdt W, Verbeke G. 2004. Early and repetitive stimulation of the arm can substantially improve the long-term outcome after stroke: a 5-year follow-up study of a randomized trial. Stroke. 35. 4:924-9 